\title{
A New Branchipolynoe (Aphroditiformia: Polynoidae) Scale worm from Deep-Sea Hydrothermal Vents in The Onnuri Vent Field on The Northern Central Indian Ridge
}

\section{Sanglyeol Kim}

Korea Institute of Ocean Science \& Technology https://orcid.org/0000-0002-6290-350X

Hyeongwoo Choi

Chung-Ang University

\section{Seong-il Eyun}

Chung-Ang University

\section{Dongsung Kim}

Korea Institute of Ocean Science \& Technology

Ok Hwan Yu ( $\square$ ohyu@kiost.ac.kr)

Korea Maritime University https://orcid.org/0000-0001-6624-0865

\section{Research}

Keywords: Polychaete, Scale worm, Hydrothermal vent, COI, Onnuri vent field (OVF), Indian Ocean, Mitochondrial Genome

Posted Date: July 7th, 2021

DOI: https://doi.org/10.21203/rs.3.rs-674600/v1

License: (9) (1) This work is licensed under a Creative Commons Attribution 4.0 International License. Read Full License 


\section{Abstract}

Background: Deep-sea hydrothermal vents are dynamic environments with exotic faunas. In this study, we found a new species of Branchipolynoe (Aphroditiformia: Polynoidae) polynoid scale worm living in the recently discovered mussel Gigantidas vrijenhoeki in deep-sea hydrothermal vents and methane seeps at depths of 2,014 - 2,023 m. Associations between scale worms and giant mussels are common in hydrothermal ecosystems.

Results: We analyzed the morphology of Branchipolynoe from the Onnuri vent field (OVF) on the northern Central Indian Ridge and sequenced the full mitochondrial genome. Based on its morphological traits and mitochondrial genes, we designated the specimens as Branchipolynoe onnuriensis n. sp., described herein. This species resembles $B$. longqiensis and $B$. tjiasmantoi, but is distinguished by its notopodial acicular lobe form and the tips of the subacicular neurochaetae. The identity of the new species was well supported by genetic distance and phylogenetic analyses of the mitochondrial coxidase subunit I (COI) gene. Genetically, the new species is closest to the Western Pacific species B. tjiasmantoi; phylogenetic analyses support the correlation between Indian Ocean and Western Pacific hydrothermal polychaetes. This study provides a foundation for exploring the evolutionary relationship between scale worms and giant mussels.

\section{Introduction}

The first hydrothermal vents were discovered on a sea ridge crest off the Galapagos Islands in 1977 [1]. Many vents continue to be discovered in global mid-ocean ridge systems, back-arc diffusion centers, and off-axis submarine volcanoes [2]. Deep-sea hydrothermal vents are dynamic environments with steep nutrient gradients and physicochemical conditions caused by volcanic and tectonic phenomena [3]. Investigations of the diversity and distribution of the deep-sea hydrothermal vent community are critical due to their unique nature [4]. Vents are commonly associated with dense communities and large biomass of organisms that are patchily distributed on the deep-sea bottom $[5,6]$. These communities contribute significantly to the production of chemically synthesized biomass and demonstrate the remarkable adaptability of life in hydrothermal ecosystems [7]. These organisms are maintained in hydrothermal habitats by chemically synthesized energy sources such as hydrogen sulfide and methane from hydrothermal mineral deposits [8].

Since the discovery of a hydrothermal vent community at the Kairei vent field near the Rodriguez Triple Junction in the Indian Ocean in 2000 [9], five hydrothermal vent ecosystems have been found along the northern Central India Ridge (CIR) and Southwest Indian Ridge (SWIR), including the Dodo, Edmond, Longqu, Solitaire, and Onnuri vent fields [10-12]. Therefore, the biogeographical connectivity of vent fauna in the Indian Ocean has become a focus of research [2]. Mid-ocean ridges of the Indian Ocean have been hypothesized as a biogeographical pathway linking vent fauna in the Western Pacific and Atlantic Ridge systems [11]. Thus, the evolutionary affinity of vent invertebrates in the Western Pacific and Indian Ocean vent communities has been proposed to assemble asymmetrically, with a positive bias in the Western Pacific [7].

Polychaetes, in suborder Aphroditiformia (Annelida), are commonly referred to as scale worms due to their dorsal scales (elytra) [12]. Scale worms are classified into 242 genera within seven families (Acoetidae, Aphroditidae, Eulepethidae, Iphionidae, Pholoidae, Polynoidae, and Sigalionidae). Scale worms are found throughout the tropics, polar regions, intertidal zones, and deep seas [13-16]. Branchiate scale worms in the genus Branchipolynoe Pettibone, 1984 live within the mantle cavities of bathymodiolin mussels in hydrothermal vents and methane seeps [17]. Notably, these scale worms have very well developed, arborescent branchiae, which are much larger than 
those of other branchiate polynoid species [18]. Members of genus Branchipolynoe are also unusual for their small scales, as most scale worms have scales that completely cover the dorsum [19]. In the Indian Ocean, Branchipolynoe scale worms have been reported from deep-sea hydrothermal vents on the SWIR [20].

Branchipolynoe species have been recorded as symbionts of host mussels; however, recent studies have suggested that they may be parasitic [21]. The polynoid Branchipolynoe seepensis has been found in mussels that inhabit hydrothermal vents and methane seeps, causing gill filament displacement and minor gill tissue damage [22]. These scale worms eat particulate organic matter filtered by the mussels, and accidentally consume mussel tissues during the feeding process; thus, they are not considered true parasites or commensals but rather kleptoparasites [23]. According to a biogeographical study of Branchipolynoe phylogenetics, the most recent common ancestor of eastern Pacific Branchipolynoe species may have inhabited methane seeps, and then migrated west to hydrothermal vents and methane seeps of the western Pacific and Indian Oceans [19].

In this study, we examined Branchipolynoe specimens collected on a survey of the hydrothermal vents of the Onnuri vent field (OVF) in 2019. We identified and described a new scale worm species and sequenced the full mitochondrial genome. Finally, we described the anatomy of the new species and evaluated its phylogenetic associations within Branchipolynoe.

\section{Materials And Methods}

\section{Specimen collection and preservation}

Specimens of G. vrijenhoeki containing Branchipolynoe were collected from deep-sea hydrothermal vents in the OVF on the northern Central Ridge of India (Additional file 1). The OVF is located along the CIR at $11^{\circ} 24.880^{\prime} \mathrm{S}$, $66^{\circ} 25.420^{\prime}$ E. All specimens were obtained at depths of 2,014 and 2,023 m using a video-guided hydraulic grab (television grab) during a Korea Institute of Ocean Science and Technology research cruise in 2019. All specimens were preserved onboard the vessel in $95 \%(\mathrm{v} / \mathrm{v})$ ethanol solution in a freezer $\left(-20^{\circ} \mathrm{C}\right)$ and then transported to a laboratory for morphological examination and phylogenetic analysis. Holotypes and a series of paratypes were deposited in Library of Marine Samples of the Korea Ocean Science \& Technology (KIOST) and the National Marine Biodiversity Institute of Korea (MABIK).

\section{Morphological examination}

We used Leica DMC 4500 cameras mounted on a Leica M205C stereomicroscope for micrography. We used the Helicon Focus v6 software (Helicon Soft Ltd., Kharkiv, Ukraine) to merge images into a stack of pictures, which was then stained with methyl green to observe the parapodial lobes and chaetae in detail. For scanning electron microscope (SEM) observations, several parapodia were isolated from the specimens, rinsed with absolute ethanol, dehydrated, coated with gold, inspected, and photographed using a Hitachi S-4300 SEM. All known Branchipolynoe species were tabulated, and several key characteristics were compared including the elytra, filaments, branchiae, dorsal cirri, notochaetae, and neurochaetae.

\section{DNA extraction, amplification, and sequencing}

The mitochondrial COI ( 700 bp) was amplified via polymerase chain reaction (PCR) using the primers polyLCO and polyHCO [24] with the D'Neasy Blood and Tissue Kit (Qiagen, Hilden, Germany) (Additional file 2). PCR amplification was performed in $20 \mu \mathrm{L}$ reaction volumes containing $10 \mu \mathrm{L} 2 \mathrm{X}$ TOPsimpe DyeMIX- 
Tenuto (Enzynomics, Korea), $1 \mu \mathrm{L}$ template DNA (10 pmol/ $\mu \mathrm{L}), 0.5 \mu \mathrm{L}$ each primer $(20 \mathrm{pmol} / \mu \mathrm{L})$, and $8 \mu \mathrm{L}$ distilled water $\left(\mathrm{dH}_{2} \mathrm{O}\right)$ under the following conditions: 1 cycle of $95^{\circ} \mathrm{C}$ for $2 \mathrm{~min}$, followed by 35 cycles of $95^{\circ} \mathrm{C}$ for $30 \mathrm{~s}, 60^{\circ} \mathrm{C}$ for $1 \mathrm{~min}$, and $72^{\circ} \mathrm{C}$ for $1 \mathrm{~min}$, with a final extension of $72^{\circ} \mathrm{C}$ for $5 \mathrm{~min}$. The PCR products were verified by $1 \%$ agarose gel electrophoresis in 1× TAE buffer.

\section{Genome sequencing and Trimming}

Two libraries (insert size, 550 bp) were constructed using the TruSeq DNA Nano 550bp kit. The libraries were sequenced using the Illumina Novaseq 6000 platform. Low-quality reads (less than Q20) were trimmed using Trim Galore! (ver. 0.6.6) and the reads having shorter than 120 bp or with unknown nucleotides ("N") were discarded. We obtained a total of $131,865,089$ reads.

\section{Mitochondria genome assembly and annotation}

After the filtering process, de novo assembly was performed using the MITOZ [25] and SPAdes (ver. 3.14.0) [26]. Putative mitochondrial contigs generated by both programs were identified and annotated on the MITOS web server [27]. The circular mitogenome was visualized using Circos (ver. 0.69-8).

\section{Phylogenetic analyses}

To reconstruct phylogenetic relationships, we constructed a dataset including the COI genes from 12 Branchipolynoe species and 1 outgroup species, Austrolaenilla antarctica (Additional file 3), which were downloaded from National Center for Biotechnology Information (NCBI) database. Multiple alignment of the coding genes was performed using MAFFT (ver. 7.475) with the default options. COI distance matrices were implemented using the MEGA X software and the Kimura two-parameter model [28] (Table 1).

We used the Bayesian information criterion $(\mathrm{BIC})$ to select the best model for phylogenetic tree reconstruction obtained using the IQ-TREE software [29]. The TPM2+F+G4 evolutionary model was the best fit for the dataset sequences. Maximum likelihood (ML) phylogeny was reconstructed using the RAxML tool [30]. ML node support was determined from a majority consensus tree constructed using 1,000 bootstrap replicates. Bayesian inference (BI) analysis was performed using MrBayes (ver. 3.2.7a) [31]. Markov chain Monte Carlo (MCMC) searches were run twice for $10^{6}$ generations with four chains, sampling every 500 generations for each analysis. The phylogenetic tree was visualized using FigTree (ver. 1.4.4).

\section{Results}

\section{Systematics}

Family Polynoidae Kinberg, 1856

Subfamily Aphroditiformia Pettibone, 1984

Genus Branchipolynoe Pettibone, 1984

Brnachipolynoe onnuriensis n. sp.

\section{Material examined}


Six specimens. Holotype (B_S_MA_00031740) and five paratypes (B_S_MS_00031741-3), collected from the OVF

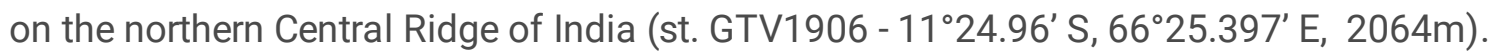

\section{Etymology and Host}

Named in honor of the discoverer of the OVF, the host is Gigantidas vrijenhoeki Jang \& Won, 2020.

\section{Description}

Body long, slightly tapered anteriorly and posteriorly, arched dorsally, and flattened ventrally, with 21 segments, including the first achaetous segment (Fig. 1A, B), and 10 pairs of elytra and elytrophores, on segments 2, 4, 5, 7, 9, $11,13,15,17$, and 19. Elytra moderately large, oval, smooth, without border papillae (Fig. 2C-F), covering anterior and posterior dorsal ends, but leaving the middle of the body partially covered by the dorsum (Fig. 1A, B). Nonelytra-bearing segments with short, smooth dorsal cirri on short, cylindrical cirrophores. Dorsal cirri with short slender tips, tapering gradually, longer than anterior and ventral cirri, not extending beyond the tips of the neurochaetae.

Prostomium ellipsoidal, bilobed with almost rounded anterior lobes. Short, conical median antenna inserted between two anterior lobes and pair of short conical palps (Fig. 1C). Median antenna and palps smooth and tapering to the slender tip. Palps extending beyond the prostomium. Prostomium lacking frontal filaments, eyes, and lateral antennae. First segment fused to prostomium with two pairs of short anterior cirri. Anterior cirri smooth and slightly slender, not exceeding the prostomium length (Fig. 1C). Thick, extended muscular pharynx with five pairs of dorsal and ventral small, sac-like terminal papillae surrounding the mouth (Fig. 2A).

Branchiae on segments 3-21 dense and arborescent, with short terminal filaments (Fig. 2B), not extending beyond the elytral border. Branchiae separated into two types, showing dorsal and ventral emergence, respectively. No discernible dorsal tubercles. Branchiae gradually decreasing in size anteriorly and posteriorly.

Parapodia subbiramous. Notopodia smaller than neuropodia, with few notochaetae projecting beyond notopodia (Additional file 4). Neuropodia large, rounded, enclosing numerous neurochaetae with rounded lobes. Notochaetae smooth, stouter, and shorter than neurochaetae (Fig. 3A). Notochaetae few, more abundant on the middle and posterior than anterior segments, slightly tapered with serrated distal part; tip rounded, shaft with inconspicuous rows (Fig. 3B-D). Neurochaetae numerous, more abundant in the middle than anterior and posterior segments, arranged as a vertical fan; tapered, with subdistal swelling and small spines along edge, serrations starting at the midpoint on only one side and extending distally.

Neurochaetae divided into supraacicular and subacicular neuroseatae. Supraacicular neurochaetae long, stout, slender tips, each with a minute hook; serrated distally and flattened on one side. Subacicular neurochaetae with slightly hooked tip, serrated parts shorter than supraacicular neurochaetae (Fig. 4).

Ventral cirri small, smooth, without papillae, and attached to the middle regions of neuropodia; projecting anteriorly (Fig. 1D). Elongated ventral papillae of female on segments 11 and 12; projecting posteriorly, reaching the subsequent segment. Elongated ventral papillae of males on segment 12, not extending beyond half the length of the subsequent segment (Fig. 1D). Pygidium small, with pair of short, thick, tapered conical anal cirri.

\section{Morphological variation}


The holotype $28 \mathrm{~mm}$ long and $13 \mathrm{~mm}$ wide, including parapodia. Paratypes vary in size, 23-31 mm long and 9-15 $\mathrm{mm}$ wide. All specimens with elongated ventral papillae on segments 11 and 12, suggesting that males were not found.

\section{Remarks}

Nine species have been described in the genus Branchipolynoe $[4,13,19,20,32,33]$. The diagnostic characteristics of the genus were determined from Branchipolynoe symmytilida and amended by Pettibone for B. seepensis [13,33]. This latter revision included the first position of the branchiae, the presence of the frontal filament, and form of the parapodium. Subsequently, Zhou (2017) published a description of B. longqiensis in the Indian Ocean and Lindgern (2019) published descriptions of five new species from the Pacific Ocean (Additional file 3). Members of the genus have 21 segments and 10 elytra; the elytra partially cover the dorsal region. Only $B$. symmytilida has frontal filaments, and all have a bilobed prostomium, except B. kajsae. In Branchipolynoen. sp, the branchiae start at the third segment, and the parapodium is subbiramous, forming a very similar shape to $B$. longqiensis and B. tjiasmantoi, but with a short, rounded notopodial acicular lobe, inconspicuous pharynx papillae, and different shapes of the tips of sub-acicular neurochaetae (Additional file 5).

\section{Phylogenetic analyses}

Among Branchipolynoe species, the mitochondrial COI genetic distance ranged from 0.056 to 0.237 , with an average of 0.175 (Table 1). The species with the closest COI genetic distance to that of $B$. onnuriensis $\mathrm{n}$. $\mathrm{sp}$. was B. tjiasmantoi from the western Pacific, with a value of 0.056 . This value is similar to those of $B$. halliseyae and $B$. kajsae (0.059), which are referred to as sister species in previous studies due to their similar morphology [19]. The second closest COI genetic distance belonged to B. longqiensis (0.099) found in the Indian Ocean.

The $\mathrm{ML}$ tree and $\mathrm{BI}$ analyses inferred from Branchipolynoe mitochondrial $\mathrm{COI}$ sequences produced a single topology for each region (Fig. 5). The phylogenetic trees isolated the Branchipolynoe species and supported a clade comprising B. onnuriensis n. sp. and B. tjiasmantoi (ML: 78\%, BI: 1).

\section{General features of mitochondrial genomes}

The complete mitochondrial genome of $B$. onnuriensis n. sp. was 16,217 bp in length, comprising 15 protein-coding genes (PCGs) (Fig. 6), 7 NADH dehydrogenase subunits (nad1-6 and nad4L), 4 cytochrome oxidase subunits (cob and cox1-3), 2 ATP synthase subunits (atp6 and atp8), and 2 small and large ribosomal RNA genes (rns and rnl). We identified 22 transfer RNA (tRNA) genes and an A+T-rich region. Among these genes, ND5 was the longest (1,525 bp) and atp8 was the shortest (160 bp). The tRNA length ranged from 64 (trnC) to 71 (trnQ), with an average length of $66.41 \mathrm{bp}$ (Table 2). No gene rearrangement was detected (Additional file 6).

\section{Base composition}

To assess the mitochondrial genome, we calculated its nucleotide composition ( $A \%, C \%, G \%, T \%, A+T \%, C+G \%), A T$ skew, and GC skew. AT and GC skew were calculated as follows: AT skew $=(A-T \%) /(A \%+T \%)$ and GC skew $=(G$ - $\mathrm{C} \%) /(\mathrm{G} \%+\mathrm{C} \%)$. The overall nucleotide composition of the complete mitochondrial genome was $28.45 \% A$, $24.44 \%$ C, $8.99 \%$ G, and 38.12\% T. The proportion of AT content (66.57\%) was 1.99 times higher than that of GC content (33.43\%) (Additional file 7). Most genes showed positive AT skew, except rns and rnl. All genes also showed negative GC skew, indicating that PCGs in B. onnuriensis $\mathrm{n}$. sp. contained a higher percentage of $\mathrm{T}$ and $\mathrm{C}$ than $A$ and $G$, except rns and rnl. 


\section{Discussion}

Branchipolynoe onnuriensis $\mathrm{n}$. sp. is the second Branchipolynoe species to be found in deep-sea hydrothermal vents in the Indian Ocean. Morphologically, $B$. onnuriensis is very similar to $B$. Iongqiensis from the Indian Ocean and $B$. tjiasmantoi from the western Pacific. To date, the genus Branchipolynoe has been described from only 10 species discovered in hydrothermal vents and methane seeps worldwide, including 5 in the eastern Pacific, 2 in the western Pacific, 1 in the Atlantic, and 2 in India; among these, B. eliseae, B. halliseyae, B. kajsae, B. meridae, and B. tjiasmantoi were recently described from the eastern and western Pacific [19]. Lindgren (2019) suggested that the most recent common ancestor of Branchipolynoe species may have lived in methane seeps in the eastern Pacific. Hydrothermal vents and methane seeps comprise similar basic ecological systems; therefore, it appears that Branchipolynoe moved west to colonize vents and seeps of the western Pacific and Indian Oceans. Future studies should elucidate Branchipolynoe migration patterns to other regions in the Indian Ocean and their evolution to adapt to these harsh environments.

The species discovered in this study was difficult to distinguish from previously discovered several species using external morphological characteristics, but showed sufficient genetic distance to classify it as a new species. It is increasingly common to describe animal species without obvious morphological differences based on molecular data alone [34]. This technique allows the reliable isolation of polynoid species, which is important for understanding the distribution and geographic patterns of this taxon [35]. Polynoids are the most diverse and widely distributed polychaete group found in hydrothermal vents and seeps, and are a good model for evaluating the biogeographic distribution of deep-sea environmental faunas [4]. Further studies of polynoids are needed to enhance our understanding of deep-sea ecosystems.

Branchipolynoe live in hydrothermal vents or methane seeps, and B. pettiboneae has been found in both. Two undescribed species have been reported from hydrothermal fields on the CIR and SWIR [36]. Branchipolynoe sp. "Dragon," a commensal scale worm found in bivalve mussels in the Longqi vent field on the SWIR, shows genetic similarity to an undescribed species (Branchipolynoe sp. "VG-2002") that was recorded and sequenced from the Kairei vent field on the CIR. Further research on Branchipolynoe species in the Indian Ocean is needed to elucidate the adaptations of animals living in vents of the CIR.

There is no consensus on the minimum COI distance required to classify a species, and each taxon has a different minimum COI distance [37]. Therefore, a minimum interspecies distance greater than the maximum interspecies distance is often applied to identify new species [38]. In polychaetes, a COI distance of $\geq 2 \%$ is considered to indicate a different species, and $\mathrm{a} \geq 10 \%$ difference is used to indicate a different genus. For the newly discovered species, the minimum genetic distance among species was 0.056 , representing a difference of $>5 \%$ from its most closely related species, $B$. tjiasmantoi. Thus, even without morphological data, the COI distances indicate that $B$. onnuriensis $\mathrm{n}$. $\mathrm{sp}$. is a new species.

The newly discovered polynoid is symbiotic to the recently discovered mussel G. vrijenhoeki. Unlike other free-living vent polynoids (e.g., Branchinotogluma), Branchipolynoe species typically inhabit the inner mantle space of Bathymodiolus mussels. Therefore, the lack of a record of symbiotic polynoids in the OVF may be due to the apparent rarity of Bathymodiolus in this region [39]. B. pettiboneae was first discovered in Gigantidas platifrons; however, most specimens have been found in Bathymodiolus mussels. Symbiotic species subsist on the byproducts of chemical synthesis by the host, and obtain protection from the external environment from the host shell [40]. Rindren (2019) found no relationship between haplotype and host mussel or depth in a new species

Page $7 / 19$ 
found in Costa Rica, and no significant within-species genetic distances at different depths or in different hosts. Branchipolynoe species are found in a variety of hosts and at a range of depths; thus, it appears that any mussel is capable of inhabiting hydrothermal vents or methane seeps can act as a suitable host. Different host bivalves adapt to different hydrothermal vents or methane seeps, and Branchipolynoe has evolved to coexist with these shellfish.

Most members of Branchipolynoe live individually inside the mussel mantle pallial cavity [41]. Sometimes two are found, but these are very rare occurrences. Among species found in hydrothermal vents, the polynoid $B$. symmytilida was found in the mussel $B$. thermophilus, and the polynoid $B$. pettiboneae was found in the mussel Bathymodiolus brevior. The polynoids $B$. Iongqiensis and $B$. tjiasmantoi were found in the mussels Bathymodiolus marisindicus and B. brevior, respectively. Branchipolynoe species have also been newly discovered in cold seeps. Branchipolynoe larvae can travel long distances between vents or among numerous ventilation systems, allowing gene flow [19]. Further studies are needed to determine whether Branchipolynoe species have host mussel preferences, how they coexist and evolve, and the role that they play in hydrothermal environments.

\section{Declarations}

\section{Acknowledgments}

We thank the researcher Sumin Kang for her kind help sorting the specimen. We also thank the cruise members of $\mathrm{R} / \mathrm{V}$ Isabu for their assistance with the fieldwork.

\section{Authors' contributions}

DK and OY: sampled the specimen, HC and SK: methodology, SK, HC, SE, and OY: interpretation, SK, HC, SE, and OY: manuscript writing, OY: supervision

\section{Funding}

This work was part of the project titled 'Understanding the deep-sea biosphere on seafloor hydrothermal vents in the Indian Ridge (no. 20170411)' funded by the Ministry of Oceans and Fisheries, Korea and Korea Institute of Ocean Science and Technology (PM62320).

\section{Availability of data and materials}

The data presented in this study are available in the main text and associated Supplementary Materials. The complete mitochondrial sequence was submitted to GenBank with an accession number MZ457523.

\section{Ethics approval and consent to participate}

\section{Consent for publication}

All authors have read and agreed to the published version of the manuscript.

\section{Competing interests}

The authors declare no conflict of interest.

\section{Author details}


${ }^{1}$ Marine Ecosystem and Biological Research Centre, KIOST, 385 Haeyang-ro, Yeongdo-gu, Busan, Korea.

2 Korea Maritime University, Dongsam 2-dong, Yeongdo-gu, 606-791, Busan, Korea.

${ }^{3}$ Department of Life Science, Chung-Ang University, 84 HeukSeok-ro, Seoul 06974, Korea.

\section{References}

1. Lonsdale P. Clustering of suspension-feeding macrobenthos near abyssal hydrothermal vents at oceanic spreading centers. Deep Res. 1977;24.

2. Beedessee G, Watanabe H, Ogura T, Nemoto S, Yahagi T, Nakagawa S, et al. High connectivity of animal populations in deep-sea hydrothermal vent fields in the central indian ridge relevant to its geological setting. PLoS One. 2013;8:e81570.

3. Ryu T, Kim JG, Lee J, Yu OH, Yum S, Kim D, et al. First transcriptome assembly of a newly discovered vent mussel, Gigantidas vrijenhoeki, at Onnuri Vent Field on the northern Central Indian Ridge. Mar Genomics. 2021;57:100819.

4. Wu X, Zhan Z, Xu K. Two new and two rarely known species of Branchinotogluma (Annelida: Polynoidae) from deep-sea hydrothermal vents of the Manus Back-Arc basin, with remarks on the diversity and biogeography of vent polynoids. Deep Res Part I Oceanogr Res Pap. 2019;149:1-20.

5. Rogers AD, Tyler PA, Connelly DP, Copley JT, James R, Larter RD, et al. The discovery of new deep-sea hydrothermal vent communities in the Southern ocean and implications for biogeography. PLoS Biol. 2012;10:e1001234.

6. Van Dover CL. Biogeography of hydrothermal vent communities along seafloor spreading centers. Trends Ecol Evol. 1990;5:242-6.

7. Van Dover CL, Humphris SE, Fornari D, Cavanaugh CM, Collier R, Goffredi SK, et al. Biogeography and ecological setting of Indian Ocean hydrothermal vents. Science. 2001;294:818-23.

8. Dubilier N, Bergin C, Lott C. Symbiotic diversity in marine animals: The art of harnessing chemosynthesis. Nat Rev Microbiol. 2008;6:725-40.

9. Hashimoto J, Ohta S, Gamo T, Chiba H, Yamaguchi T, Tsuchida S, et al. First hydrothermal vent communities from the Indian Ocean discovered. Zoolog Sci. 2001;18:717-21.

10. Kim JG, Lee J. A new species of the genus Smacigastes Ivanenko \& Defaye, 2004 (Tegastidae, Harpacticoida, Copepoda) from the Onnuri Vent Field in the Indian Ocean. Zoosystematics Evol. 2020;96:699-714.

11. Mevel C, Tamaki K, German CR, Baker ET, The FST. FUJI ST. Hydrothermal activity along the southwest Indian ridge. Nature. 1998;395:490-93.

12. Rouse GW, Fauchald K. Cladistics and Polychaetes. Zool Scr. 1997;26:139-204.

13. Pettibone M. A new scale-worm commensal with deep-sea mussels in the seep-sites at the Florida escarpment in the eastern Gulf of Mexico (Polychaeta: Polynoidae: Branchipolynoinae). Proc Biol Soc Washingt. 1986;99:444-51.

14. Glasby CJ, Hutchings PA. A new species of Marphysa Quatrefages, 1865 (Polychaeta: Eunicida: Eunicidae) from northern Australia and a review of similar taxa from the Indo-west Pacific, including the genus Nauphanta Kinberg, 1865. Zootaxa. 2010;45:29-45. 
15. Wiklund H, Nygren A, Pleijel F, Sundberg P. Phylogeny of Aphroditiformia (Polychaeta) based on molecular and morphological data. Mol Phylogenet Evol. 2005;37:494-502.

16. Norlinder E, Nygren A, Wiklund H, Pleijel F. Phylogeny of scale-worms (Aphroditiformia, Annelida), assessed from 18SrRNA, 28SrRNA, 16SrRNA, mitochondrial cytochrome c oxidase subunit I (COI), and morphology. Mol Phylogenet Evol. 2012;65:490-500.

17. Desbruyères $D$, Hashimoto J, Fabri MC. Composition and biogeography of hydrothermal vent communities in western pacific back-arc basins. Geophys Monogr Ser. 2006;166:215-34.

18. Hourdez S, Jouin-Toulmond C. Functional anatomy of the respiratory system of Branchipolynoe species (Polychaeta, Polynoidae), commensal with Bathymodiolus species (Bivalvia, Mytilidae) from deep-sea hydrothermal vents. Zoomorphology. 1998;118:225-33.

19. Lindgren J, Hatch AS, Hourdez S, Seid CA, Rouse GW. Phylogeny and biogeography of Branchipolynoe (polynoidae, phyllodocida, aciculata, annelida), with descriptions of five new species from methane seeps and hydrothermal vents. Diversity. 2019;11:1-39.

20. Zhou Y, Zhang D, Lu B, Wang C. Description of a new branchiate scale-worm (Polychaeta: Polynoidae) from the hydrothermal vent on Southwest Indian Ocean Ridge. Zootaxa. 2017;4282:123-34.

21. Bebianno MJ, Cardoso C, Gomes T, Blasco J, Santos RS, Colaço A. Metal interactions between the polychaete Branchipolynoe seepensis and the mussel Bathymodiolus azoricus from Mid-Atlantic-Ridge hydrothermal vent fields. Mar Environ Res. 2018;135:70-81.

22. Ward ME, Shields JD, Van Dover CL. Parasitism in species of Bathymodiolus (Bivalvia: Mytilidae) mussels from deep-sea seep and hydrothermal vents. Dis Aquat Organ. 2004;62:1-16.

23. Britayev TA, Martin D, Krylova EM, Von Cosel R, Aksiuk TS. Life-history traits of the symbiotic scale-worm Branchipolynoe seepensis and its relationships with host mussels of the genus Bathymodiolus from hydrothermal vents. Mar Ecol. 2007;28:36-48.

24. Carr CM, Hardy SM, Brown TM, Macdonald TA, Hebert PDN. A tri-oceanic perspective: DNA barcoding reveals geographic structure and cryptic diversity in Canadian polychaetes. PLoS One. 2011;6:e22232.

25. Meng G, Li Y, Yang C, Liu S. MitoZ: A toolkit for animal mitochondrial genome assembly, annotation and visualization. Nucleic Acids Res. 2019;47:e63.

26. Bankevich A, Nurk S, Antipov D, Gurevich AA, Dvorkin M, Kulikov AS, et al. SPAdes: A new genome assembly algorithm and its applications to single-cell sequencing. J Comput Biol. 2012;19:455-77.

27. Bernt M, Donath A, Jühling F, Externbrink F, Florentz C, Fritzsch G, et al. MITOS: Improved de novo metazoan mitochondrial genome annotation. Mol Phylogenet Evol. 2013;69:313-9.

28. Kumar S, Stecher G, Li M, Knyaz C, Tamura K. MEGA X: Molecular evolutionary genetics analysis across computing platforms. Mol Biol Evol. 2018;35:1547-9.

29. Kalyaanamoorthy S, Minh BQ, Wong TKF, Von Haeseler A, Jermiin LS. ModelFinder: Fast model selection for accurate phylogenetic estimates. Nat Methods. 2017;14:587-9.

30. Kozlov AM, Darriba D, Flouri T, Morel B, Stamatakis A. RAxML-NG: A fast, scalable and user-friendly tool for maximum likelihood phylogenetic inference. Bioinformatics. 2019;35:4453-5.

31. Ronquist F, Huelsenbeck JP. MrBayes 3: Bayesian phylogenetic inference under mixed models. Bioinformatics. 2003;19:1572-4.

32. Miura T, Hashimoto J. Two new branchiate scale-worms (Polynoidae: Polychaeta) from the hydrothermal vent of the Okinawa through and the volcanic seamount off Chichijima Island. Proc Biol Soc Washingt. 
1991;104:166-74.

33. Pettibone M. A new scale-worm commensal with deepsea mussels on the Galapagos hydrothermal vent (Polychaeta, Polynoidae). Proc Biol Soc Wash. 1984;97:226-39.

34. Halt MN, Kupriyanova EK, Cooper SJB, Rouse GW. Naming species with no morphological indicators: Species status of Galeolaria caespitosa (Annelida:Serpulidae) inferred from nuclear and mitochondrial gene sequences and morphology. Invertebr Syst. 2009;23:205-22.

35. Nygren A. Cryptic polychaete diversity: A review. Zool Scr. 2014;43:172-83.

36. Copley JT, Marsh L, Glover AG, Hühnerbach V, Nye VE, Reid WDK, et al. Ecology and biogeography of megafauna and macrofauna at the first known deep-sea hydrothermal vents on the ultraslow-spreading Southwest Indian Ridge. Sci Rep Nature Publishing Group. 2016;6:1-13.

37. Berriman JS, Ellingson RA, Awbrey JD, Rico DM, Valdés ÁA, Wilson NG, et al. A biting commentary: Integrating tooth characters with molecular data doubles known species diversity in a lineage of sea slugs that consume “killer algae.". Mol Phylogenet Evol. 2018;126:356-70.

38. Meier R, Zhang G, Ali F. The use of mean instead of smallest interspecific distances exaggerates the size of the "barcoding gap" and leads to misidentification. Syst Biol. 2008;57:809-13.

39. McKiness ZP, McMullin ER, Fisher CR, Cavanaugh CM. A new bathymodioline mussel symbiosis at the Juan de Fuca hydrothermal vents. Mar Biol. 2005;148:109-16.

40. Company R, Serafim A, Cosson R, Fiala-Médioni A, Dixon DR, Bebianno MJ. Adaptation of the antioxidant defence system in hydrothermal-vent mussels (Bathymodiolus azoricus) transplanted between two MidAtlantic Ridge sites. Mar Ecol. 2007;28:93-9.

41. Plouviez S, Daguin-Thiébaut C, Hourdez S, Jollivet D. Juvenile and adult scale worms branchipolynoe seepensis in Lucky Strike hydrothermal vent mussels are genetically unrelated. Aquat Biol. 2008;3:79-87.

\section{Tables}

Table 1 Kimura two-parameter distance matrix of genus Branchipolynoe taxon COI sequences. 1. Branchipolynoe symmytilida, 2. B. seepensis, 3. B. pettiboneae, 4. B. longqiensis, 5. B. eliseae, 6. B. halliseyae, 7. B. kajsae, 8. B. meridae, 9. B. tjiasmantoi, 10. B. Branchipolynoe sp. “Dragon," 11. Branchipolynoe sp. "VG-2002," 12. B. onnuriensis n. sp., and 13. Austrolaenilla antarctica 


\begin{tabular}{|c|c|c|c|c|c|c|c|c|c|c|c|c|}
\hline & 1 & 2 & 3 & 4 & 5 & 6 & 7 & 8 & 9 & 10 & 11 & 12 \\
\hline 1 & & & & & & & & & & & & \\
\hline 2 & 0.204 & & & & & & & & & & & \\
\hline 3 & 0.223 & 0.183 & & & & & & & & & & \\
\hline 4 & 0.223 & 0.191 & 0.068 & & & & & & & & & \\
\hline 5 & 0.102 & 0.185 & 0.189 & 0.209 & & & & & & & & \\
\hline 6 & 0.199 & 0.071 & 0.182 & 0.201 & 0.195 & & & & & & & \\
\hline 7 & 0.197 & 0.066 & 0.184 & 0.199 & 0.197 & 0.059 & & & & & & \\
\hline 8 & 0.096 & 0.205 & 0.216 & 0.237 & 0.087 & 0.214 & 0.193 & & & & & \\
\hline 9 & 0.217 & 0.192 & 0.131 & 0.110 & 0.237 & 0.195 & 0.196 & 0.240 & & & & \\
\hline 10 & 0.226 & 0.194 & 0.073 & 0.004 & 0.212 & 0.204 & 0.195 & 0.233 & 0.115 & & & \\
\hline 11 & 0.226 & 0.200 & 0.075 & 0.006 & 0.211 & 0.210 & 0.209 & 0.247 & 0.117 & 0.010 & & \\
\hline 12 & 0.219 & 0.207 & 0.110 & 0.099 & 0.237 & 0.228 & 0.215 & 0.225 & 0.056 & 0.104 & 0.107 & \\
\hline 13 & 0.339 & 0.298 & 0.308 & 0.301 & 0.320 & 0.281 & 0.294 & 0.335 & 0.294 & 0.309 & 0.313 & 0.306 \\
\hline
\end{tabular}

Table 2 Annotation of the Branchipolynoe onnuriensis n. sp. mitochondrial genome 


\begin{tabular}{|c|c|c|c|c|c|}
\hline Gene & Strand & Position & $\begin{array}{l}\text { Length } \\
\text { (bp) }\end{array}$ & Initiation codon & Stop codon \\
\hline $\operatorname{trn} X$ & + & $1,099-1,666$ & 68 & & \\
\hline nad2 & + & $1,194-2,055$ & 862 & ACC & ACC \\
\hline $\operatorname{cox} 1$ & + & $2,173-3,694$ & 1,522 & CGC & ATT \\
\hline $\operatorname{cox} 2$ & + & $3,764-4,430$ & 667 & ATG & TGA \\
\hline $\operatorname{trnD}$ & + & $4,458-4,524$ & 67 & & \\
\hline atp8 & + & $4,524-4,683$ & 160 & ATG & TAA \\
\hline $\operatorname{trn} Y$ & + & $4,681-4,748$ & 68 & & \\
\hline $\operatorname{cox} 3$ & + & $4,764-5,526$ & 763 & TTT & TCT \\
\hline $\operatorname{trnQ}$ & + & $5,533-5,603$ & 71 & & \\
\hline cob & + & $5,638-6,757$ & 1,120 & ATC & ATT \\
\hline $\operatorname{trnL2}$ & + & $6,764-6,831$ & 68 & & \\
\hline $\operatorname{trnF}$ & + & $6,831-6,898$ & 68 & & \\
\hline $\operatorname{trn} E$ & + & $6,905-6,969$ & 65 & & \\
\hline $\operatorname{trnP}$ & + & $6,970-7,034$ & 65 & & \\
\hline nad4 & + & $7,223-8,507$ & 1,285 & TGA & ATA \\
\hline $\operatorname{trnG}$ & + & $8,524-8,589$ & 66 & & \\
\hline trns2 & + & $8,652-8,719$ & 68 & & \\
\hline nad1 & + & $8,737-9,628$ & 892 & ATT & TTA \\
\hline trnl & + & $9,650-9,718$ & 69 & & \\
\hline $\operatorname{trnK}$ & + & $9,723-9,790$ & 68 & & \\
\hline nad3 & + & $9,776-10,125$ & 350 & ATG & TAA \\
\hline $\operatorname{trnN}$ & + & $10,149-10,213$ & 65 & & \\
\hline nad6 & + & $10,274-10,763$ & 490 & ATG & TAA \\
\hline trnW & + & $10,783-10,847$ & 65 & & \\
\hline atp6 & + & $10,976-11,537$ & 562 & AAT & CAC \\
\hline $\operatorname{trnR}$ & + & $11,547-11,611$ & 65 & & \\
\hline $\operatorname{trnH}$ & + & $11,612-11,676$ & 65 & & \\
\hline nad5 & + & $11,742-13,266$ & 1,525 & TCT & ATT \\
\hline $\operatorname{trnT}$ & + & $13,394-13,459$ & 66 & & \\
\hline nad4L & + & $13,459-13,762$ & 304 & ATG & TAA \\
\hline
\end{tabular}




\begin{tabular}{|llll|}
$\operatorname{trnC}$ & + & $13,779-13,842$ & 64 \\
\hline $\operatorname{trnM}$ & + & $13,848-13,912$ & 65 \\
\hline $\operatorname{rns}$ & + & $13,910-14,728$ & 819 \\
$\operatorname{trnV}$ & + & $14,722-14,785$ & 64 \\
\hline $\operatorname{rnl}$ & + & $14,764-16,064$ & 1,301 \\
\hline $\operatorname{trnL} 1$ & + & $16,080-16,145$ & 66 \\
\hline $\operatorname{trn} A$ & + & $16,146-16,210$ & 65 \\
\hline
\end{tabular}

\section{Figures}
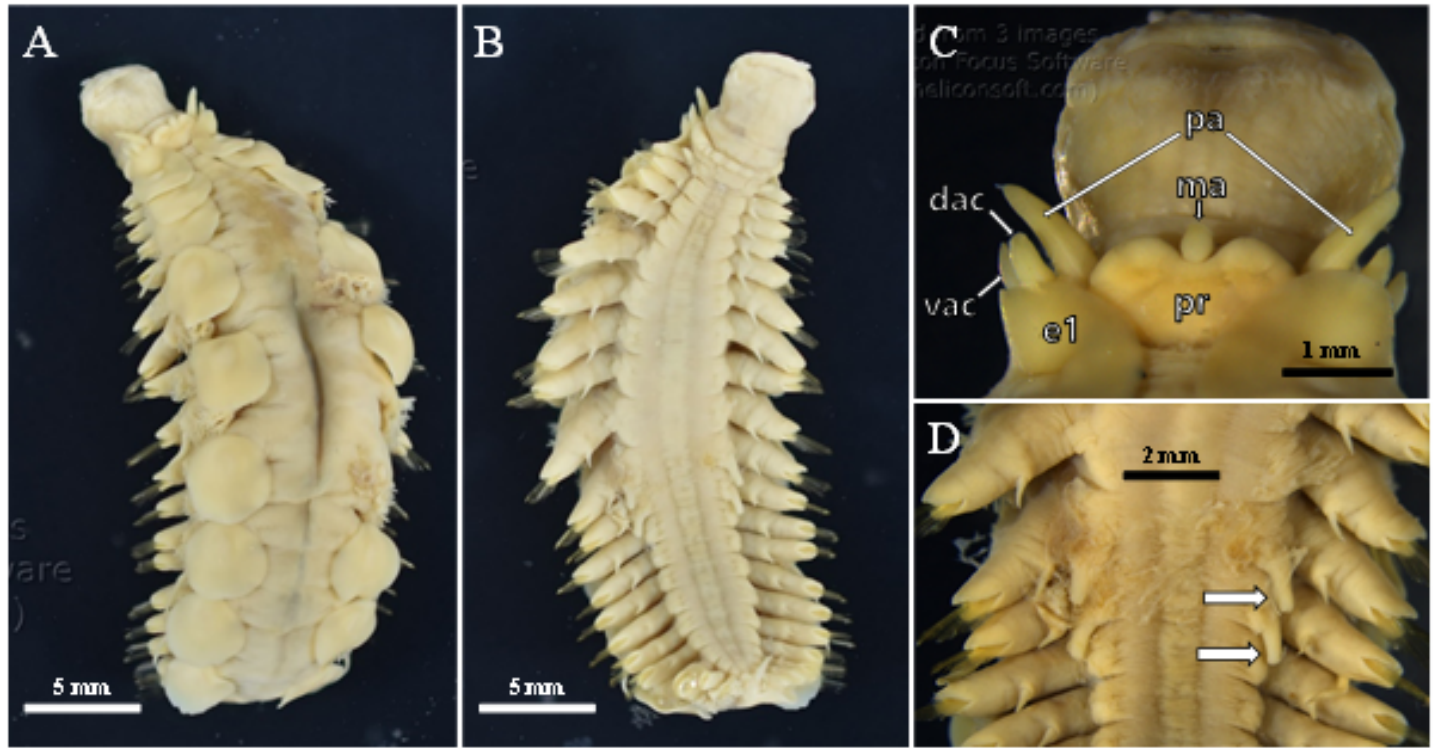

\section{Figure 1}

Branchipolynoe onnuriensis n. sp. holotype, female. A) Dorsal view. B) Ventral view. C) Head and anterior segments in dorsal view. D) Mid-body in ventral view; arrows indicate elongated ventral papillae in segments 11 and 12. Abbreviations: pa, palps; ma, median antenna; pr, prostomim; e1, first elytron (attached to segment 2); dac, dorsal anterior cirrus; vac, ventral anterior cirrus 


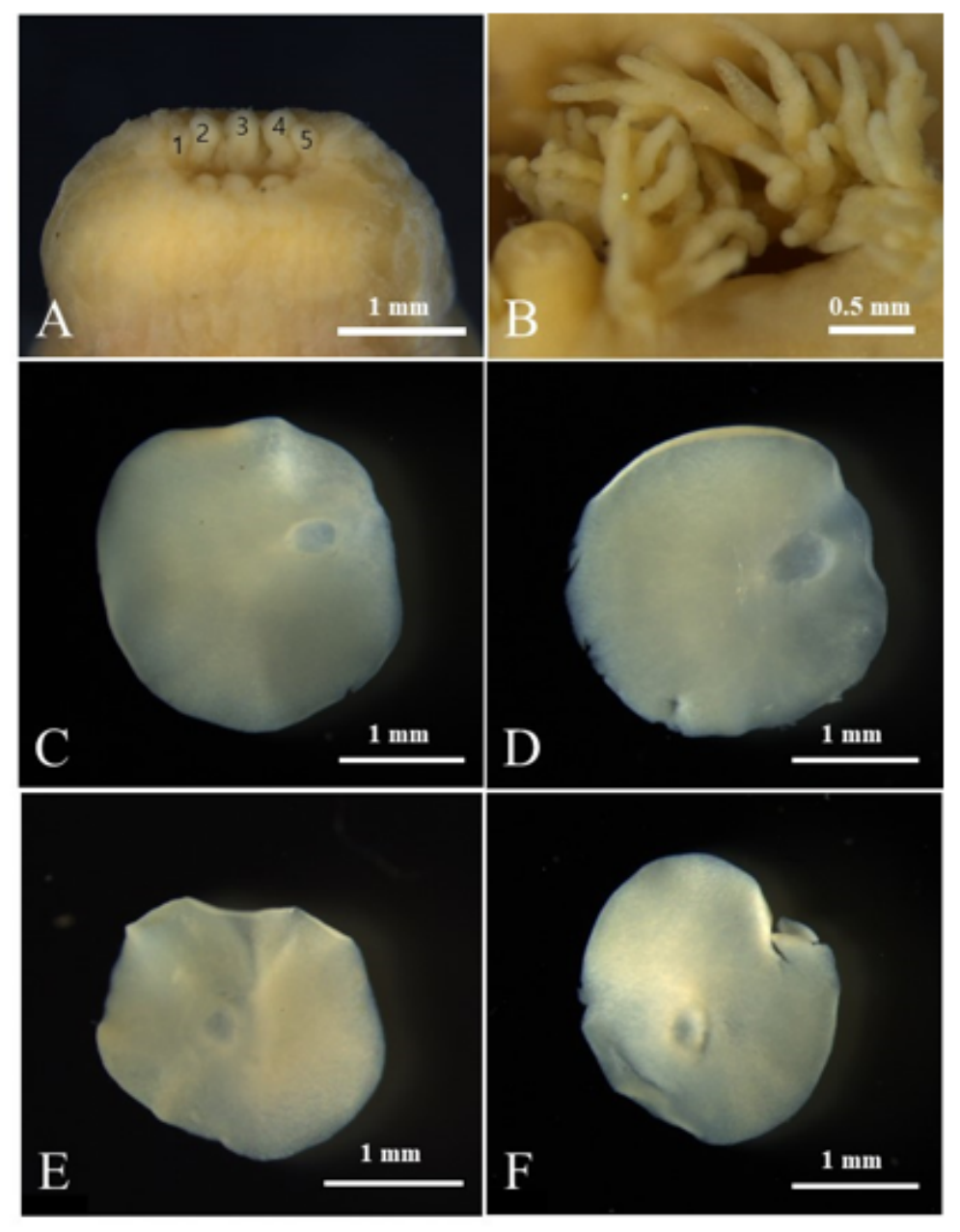

Figure 2

Branchipolynoe onnuriensis n. sp. paratype 5. A) Frontal view of proboscis. B) Branchia from segment 10. C) Left 4th elytron from segment 7. D) Left 6th elytron from segment 11. E) Left 8th elytron from segment 15. F) Left 9th elytron from segment 17 


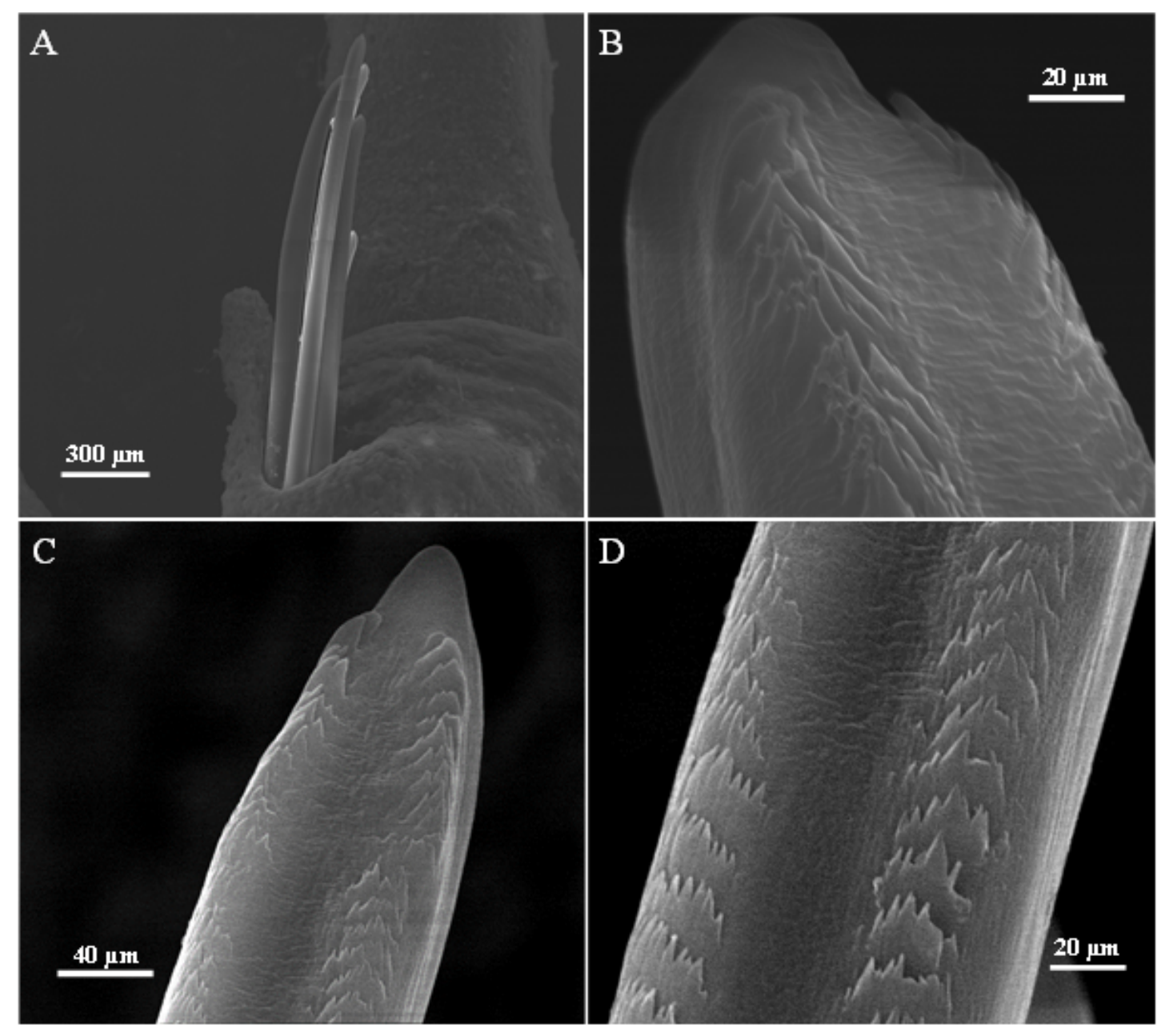

Figure 3

Branchipolynoe onnuriensis n. sp. paratype 5, female, showing left parapodum on segment 4. A) Magnified to show notochaetae view. B-D) Detail of notochaeta tips

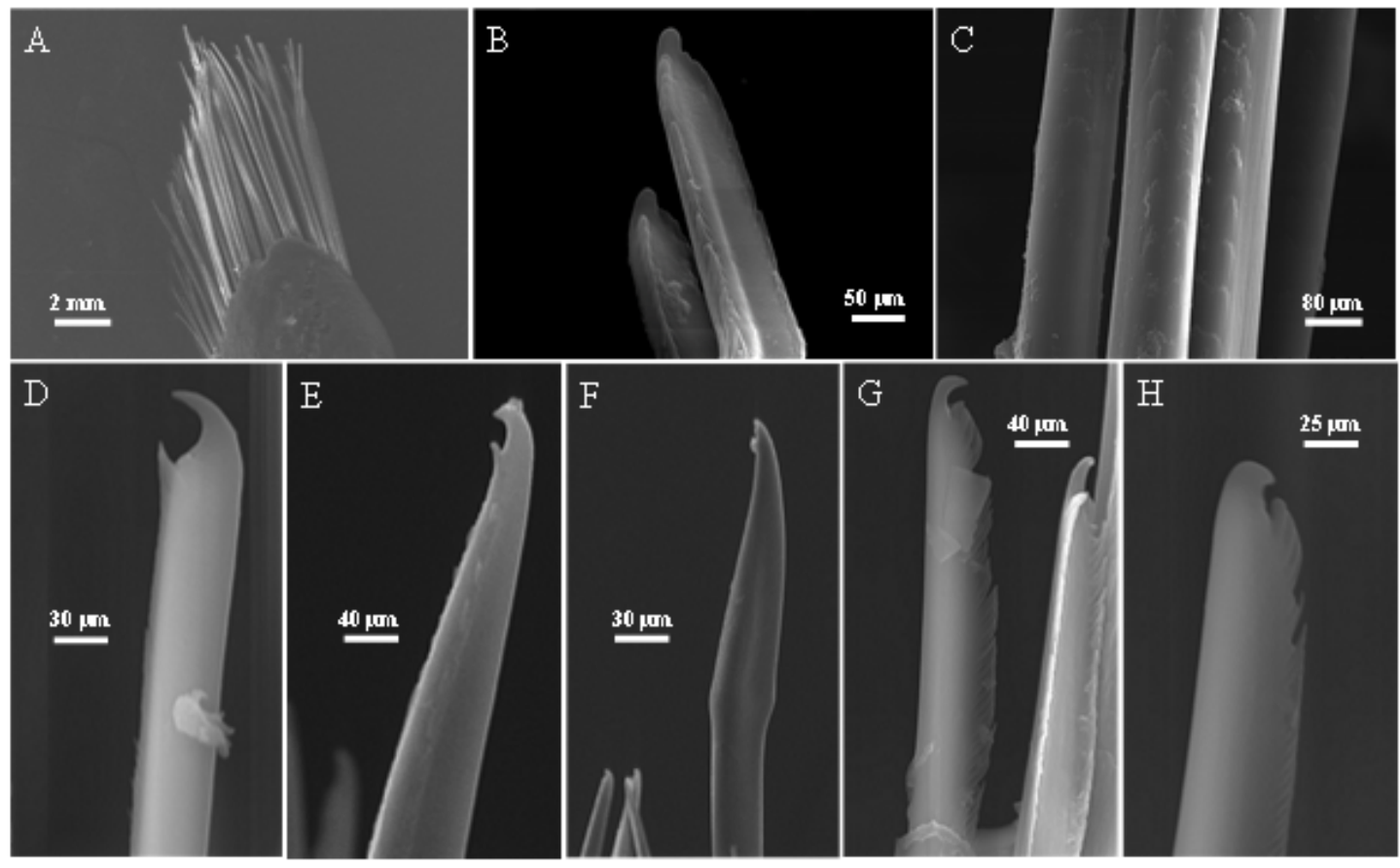


Figure 4

Branchipolynoe onnuriensis n. sp. paratype 5, female, showing left parapodium on segment 6. A) Neurochaetae. B-C) Magnified to show supraaciular neurochaetae. D-F) Detail of supraacicular neurochaeta tips. G-H) Detail of subacicular neurochaeta tips

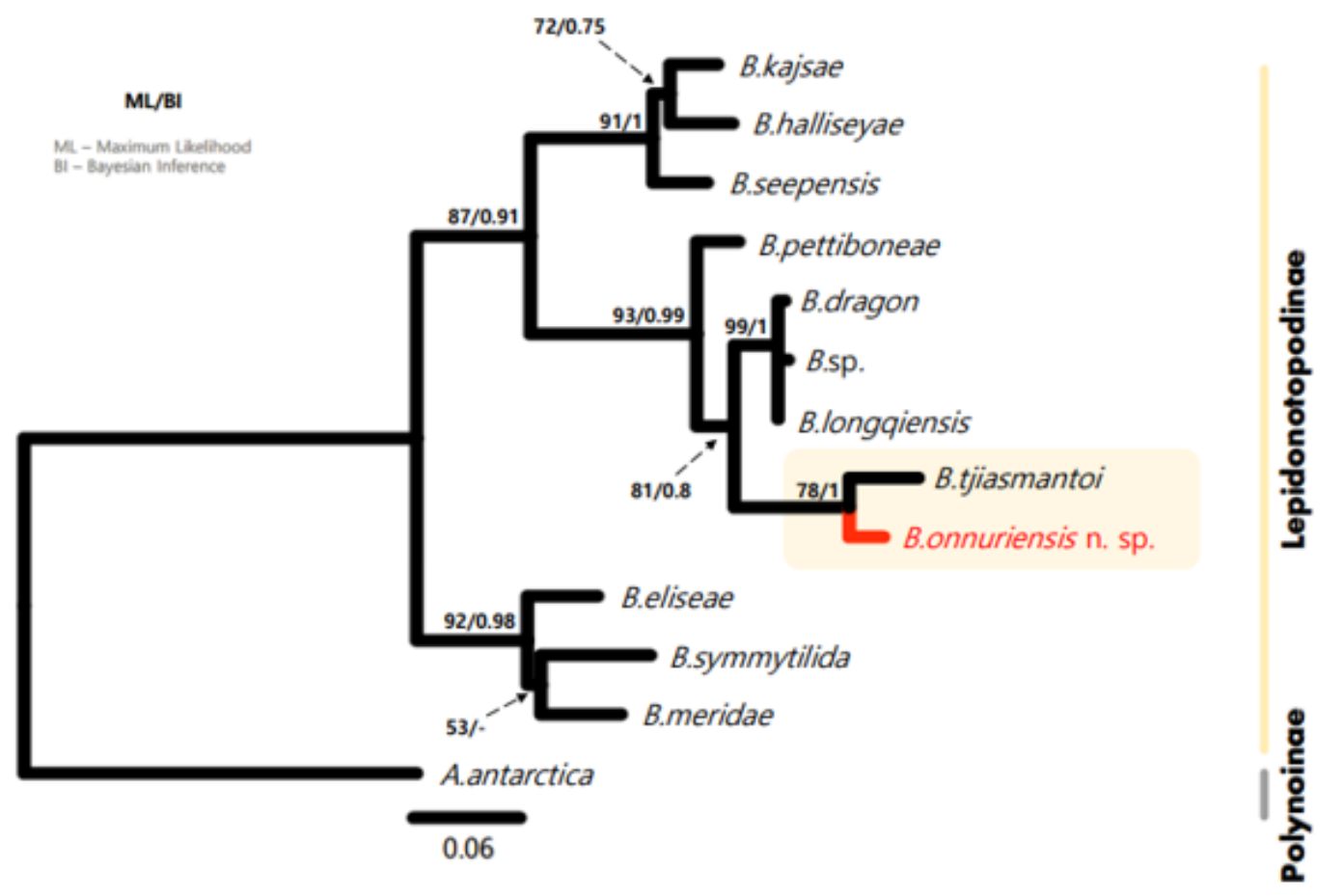

\section{Figure 5}

Maximum likelihood (ML) tree inferred from mitochondrial cytochrome c oxidase I (COI) sequences of genus Branchipolynoe. The COI sequence of Austrolaenilla antarctica was used as an outgroup. Numbers at nodes represent $\mathrm{ML}$ and Bayesian inference $(\mathrm{BI})$ support values 


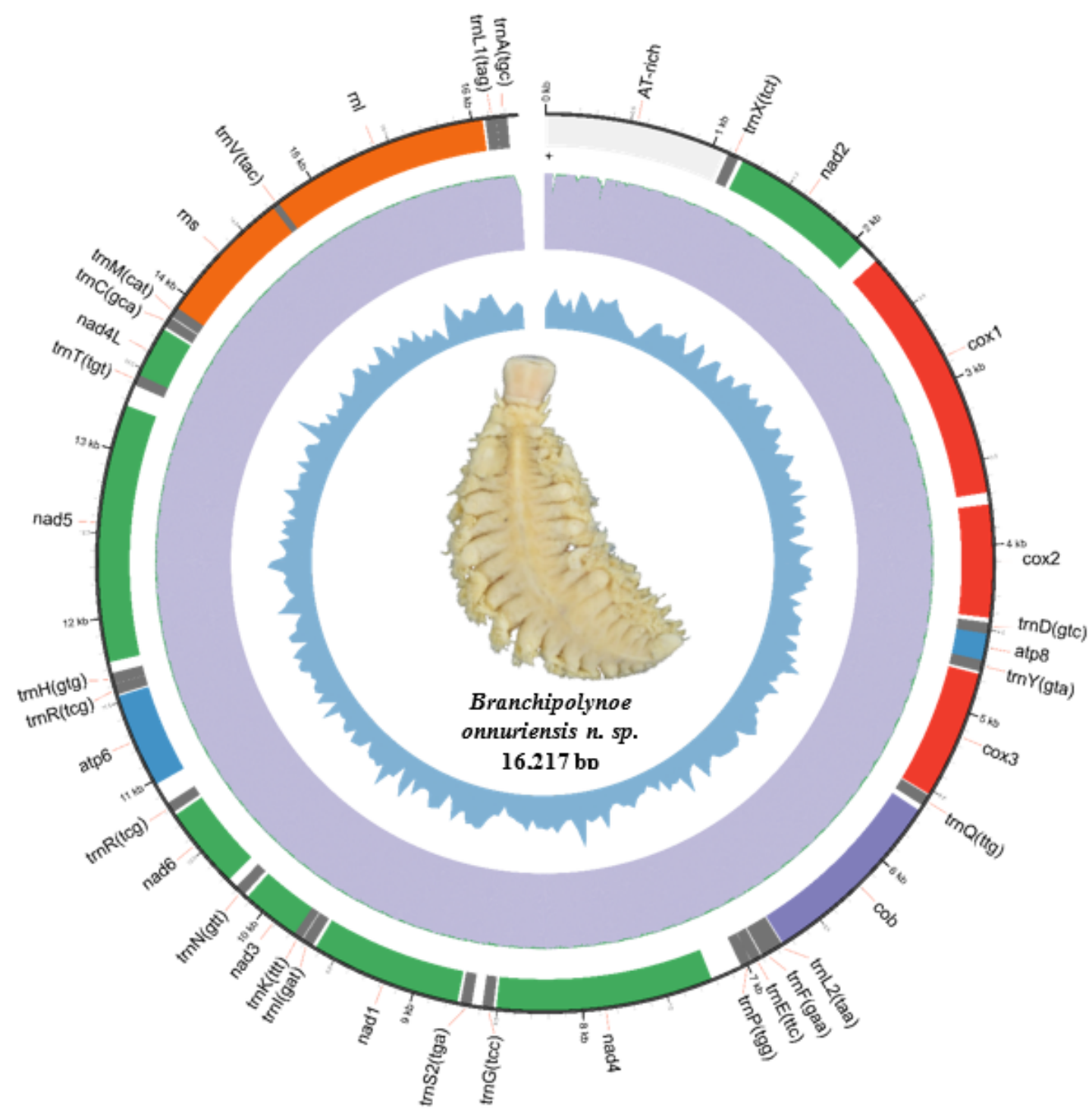

Figure 6

Circular map of the complete mitochondrial genome of Branchipolynoe onnuriensis $\mathrm{n}$. sp. Outer to inner circles represent the (i) positions of annotated genes, (ii) sequencing depth, (iii) GC content. The total mtDNA length was $16,217 \mathrm{bp}$

\section{Supplementary Files}

This is a list of supplementary files associated with this preprint. Click to download.

- Additionalfile2.docx

- Additionalfile3.docx

- Additionalfile5.docx

- Additionalfile7.docx

- Additionalfile1.docx

- Additionalfile4.docx 
- Additionalfile6.docx

Page 19/19 